\title{
Rubella and Congenital Rubella Syndrome in the Philippines: A Systematic Review
}

\author{
Anna Lena Lopez, ${ }^{1}$ Peter Francis N. Raguindin, ${ }^{1}$ Maria Asuncion Silvestre, ${ }^{2,3}$ \\ Xenia Cathrine J. Fabay, ${ }^{2,4}$ Ariel B. Vinarao, ${ }^{2}$ and Ricardo Manalastas ${ }^{2}$ \\ ${ }^{1}$ University of the Philippines Manila, National Institutes of Health, Manila, Philippines \\ ${ }^{2}$ University of the Philippines Manila, Philippine General Hospital, Manila, Philippines \\ ${ }^{3}$ Kalusugan ng Mag-Ina, Inc (Health of the Mother and Child), Quezon City, Philippines \\ ${ }^{4}$ Baguio General Hospital and Medical Center, Benguet, Philippines
}

Correspondence should be addressed to Anna Lena Lopez; annalenalopez@gmail.com

Received 29 July 2016; Revised 25 November 2016; Accepted 1 December 2016

Academic Editor: Alessandro Mussa

Copyright (C) 2016 Anna Lena Lopez et al. This is an open access article distributed under the Creative Commons Attribution License, which permits unrestricted use, distribution, and reproduction in any medium, provided the original work is properly cited.

Background. As part of regional elimination efforts, rubella-containing vaccines (RCV) have recently been introduced in the Philippines, yet the true burden of rubella and congenital rubella syndrome (CRS) in the country is largely unknown. Objective. To provide baseline information on rubella and CRS prior to routine vaccine introduction in the Philippines. Methods. We conducted a systematic literature review on rubella and CRS in the Philippines, including a cross-sectional study conducted in 2002 among 383 pregnant women attending the obstetric outpatient clinic of the Philippine General Hospital to assess rubella susceptibility of women of childbearing age. Results. 15 locally published and unpublished studies were reviewed. Susceptibility to rubella among women of childbearing age was higher in rural communities. Retrospective reviews revealed congenital heart diseases, cataracts, and hearing impairments to be most common presentations in children of CRS. In the cross-sectional study, 59 (15.4\%) of the 383 pregnant women enrolled were seronegative for rubella IgG. Conclusion. Similar to other countries introducing RCV, it was only recently that surveillance for rubella has been established. Previous studies show substantial disabilities due to CRS and a substantial proportion of susceptible women who are at risk for having babies affected with CRS. Establishment of CRS surveillance and enhanced awareness on rubella case detection should be prioritized.

\section{Introduction}

Rubella is a mild viral infection that usually manifests with fever and rash. Its public health significance primarily lies in its ability to cause congenital rubella syndrome (CRS) that results in devastating malformations and significant longterm disability [1-3]. Rubella infection has a teratogenic effect on the developing embryo, which may cause abortion if a woman is infected early in the gestational period or if pregnancy continues, may result in major cardiac anomalies, sensorineural hearing loss, cataracts, or death.

With the use of effective rubella vaccines, rubella was targeted for elimination in two regions of the World Health Organization (WHO) by 2015. But by the end of 2015, only the Region of the Americas was declared to be free of endemic rubella transmission. Worldwide, use of rubellacontaining vaccine (RCV) is increasing but despite RCV introduction in $74 \%$ of 194 WHO member states, in 2014, global infant immunization coverage remained low at $46 \%$ [4]. Surveillance for rubella and CRS is crucial in monitoring the impact of immunization programs to assess disease burden before and after RCV introduction. Although rubella surveillance is being conducted in most countries in conjunction with measles surveillance, surveillance activities for CRS, particularly in developing countries, have proven to be more challenging. Out of 194 member states, only 75 countries began reporting in 2000, which increased to 114 in 2014 but only 14 countries reported positive case identification $[4,5]$. Thus, the true burden of CRS remains underestimated [6]. 
Since 2003, the Western Pacific Region of the World Health Organization (WHO) has resolved to accelerate the control of rubella and prevention of CRS through integration with measles elimination activities [7]. In October 2014, the Western Pacific Region included rubella including CRS elimination as one of eight regional immunization goals specified by the Regional Framework for Implementation of the Global Vaccine Action Plan in the Western Pacific [8].

In the Philippines, RCVs, either singly or in combination with measles and mumps vaccines, had been available in the private sector for more than two decades $[9,10]$ but this sector is estimated to cover only $5 \%-10 \%$ of the population. RCV was only included in the country's Expanded Programme of Immunization (EPI) in 2010 and given routinely to all infants in 2011 at 12 months of age. Since 2015, through a schoolbased immunization strategy, children are given a second dose of RCV at school entry (7 years of age) to ensure that children receive at least two doses of measles-containing vaccines. No adult immunization is provided in the public sector and rubella serologic screening of pregnant women is not mandated by the government.

Surveillance for rubella was integrated into the measles surveillance in 2010; however passive laboratory-confirmed surveillance for rubella has been conducted since 2005 . In 2009 and 2010, there were 310 and 1,092 serologically confirmed rubella cases out of 1,279 and 4,085 specimens tested, respectively, nationwide [11]. Because there is minimal baseline information on the burden of rubella in the Philippines, we conducted a systematic review of studies on rubella susceptibility, as well as a review on CRS to provide information on rubella and CRS prior to routine vaccine introduction.

\section{Methods}

2.1. Systematic Review. For the systematic review, published and unpublished studies on rubella were sought. PubMed searches were performed using the search terms "Philippines" and "rubella" without any limitations on dates. References of the identified publications were reviewed. Literature search in the Philippine databases, namely, HERDIN (Health Research Information and Development Network) and PIMEDICUS (Philippine Index Medicus), was performed using the search terms "rubella," "CRS," or "congenital infection." HERDIN and PIMEDICUS include both locally published and unpublished works. Content experts and specialists were also asked for ongoing and unpublished works on the subject that we may have missed in the local and international database search. Two authors (ALL and PFR) reviewed the retrieved articles and tabulated information in Microsoft Excel $^{\mathrm{TM}}$.

2.2. Seroprevalence Survey. To determine the proportion of women who were susceptible, that is, seronegative for rubella, a cross-sectional study of pregnant women who consulted in the obstetric outpatient clinic of the Philippine General Hospital (PGH) in the city of Manila for antenatal care was conducted in 2001-2002. Sample size was computed based on the seroprevalence study of Alday [14] that 27\% were seronegative in the urban population, and using an interval of 5 with a $95 \%$ confidence level, and a $25 \%$ dropout rate, then a minimum of 373 pregnant women were required. After obtaining informed consent, data collection forms were completed specifically noting the following: age, occupation, educational attainment, age of gestation, number of previous gestations, and history of rubella immunization. Blood was obtained from the subjects and stored at $-20^{\circ} \mathrm{C}$ until ELISA for rubella was performed. Rubella-specific IgG was tested using commercially available enzyme-linked immunosorbent assay kit (CAPTIA ${ }^{\mathrm{TM}}$; Trinity Biotech, Clark Laboratories, TX, USA). ELISA was performed following the manufacturer's instructions.

Data was entered in Microsoft Excel and analysed using Stata $7^{\mathrm{TM}}$ (Stata Corporation, TX, USA). Descriptive statistics for maternal data (age, educational attainment, number of previous gestations, age of gestation, occupation, and history of rubella immunization) and 95\% confidence intervals (CI) were calculated. Tests for association of above factors with rubella susceptibility were determined using chi-square test or Fisher's exact test when data were sparse, and statistical significance was set at $p<0.05$. The study was reviewed and approved by the University of the Philippines Manila-Review Ethics Board prior to patient enrollment. Written informed consent was obtained. Women who had no detectable rubella IgG were informed of the result and advised on the need for immunization.

\section{Results}

3.1. Systematic Literature Review. Our search yielded 11 locally published $[10,12-21]$ and 4 unpublished studies [2225] (Figure 1), none of which were indexed in PubMed. From 1973-1997, 5 rubella seroprevalence studies were published, 4 of which were conducted in Metro Manila with one including a rural area [10, 12-14], and 1 was in urban Cebu [15] (Table 1). Rubella susceptibility was higher in studies conducted from the 1970s-1980s [10, 12-14] as well as from participants in the rural areas $[10,14]$.

Ten studies were on CRS [15-24] with one study on pregnancy outcomes [25]. Of the 10 studies on CRS, seven were published (Table 1) and three were unpublished (Table 2). Nine of the 10 studies were retrospective reviews and only one was cross-sectional [18]. Seven of the studies were conducted in a tertiary public hospital (PGH) located in Manila [16, 17, 19, 20, 22-24]. Among published studies, one study proportionately described CRS in congenital cataract cases [19] and two studies described CRS on patients with hearing impairment [18, 21]. Among all patients with congenital cataract, CRS was found to be the most common cause of secondary congenital cataract $(28.7 \%$ of all congenital cataracts) [19]. CRS was also the most common cause of secondary congenital sensorineural hearing loss [18, 21]. In a prospective study students in a School for the Deaf, 28 (4.8\%) children reported other associated impairments (e.g., cataract, blindness, and cardiac defect) suggesting CRS, while $136(23.5 \%)$ reported possible maternal rubella exposure [18].

Only one unpublished study reported on pregnancy outcomes among women who were tested for rubella titers. Out of 124 pregnant women, there were 4 (3.2\% of all tested) 


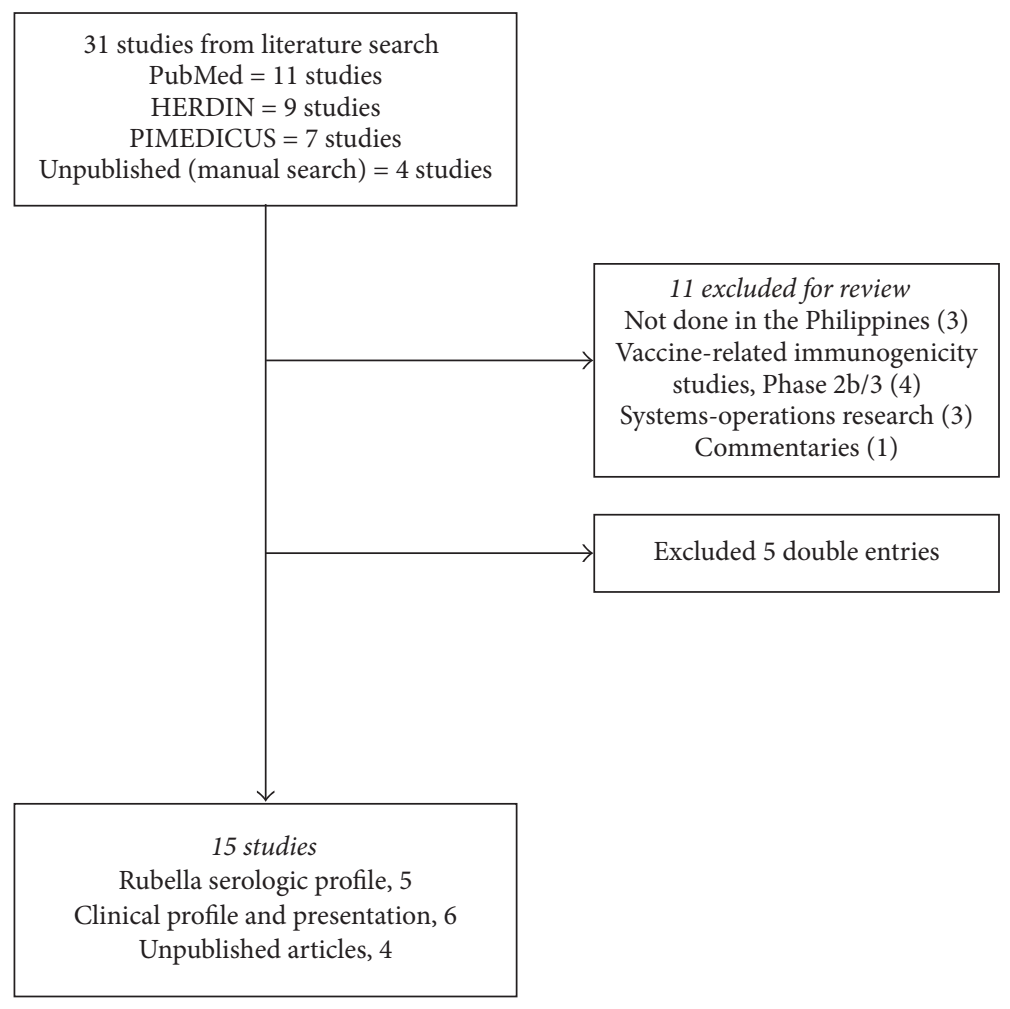

Figure 1: Flow of articles reviewed.

cases of maternal rubella infection: 1 had fetal death in utero, and 3 babies were diagnosed with CRS [25].

Two studies characterized the clinical profile of CRS among physician-diagnosed cases $[17,20]$. The most common clinical manifestations of CRS in the reports were cataract [20] or congenital heart disease [17]. Patent ductus arteriosus and pulmonary stenosis were the most common cardiac manifestations seen in about $45 \%$ of the reviewed cases of children with CRS [17].

3.2. Cross-Sectional Study. From March 5, 2002, to June 5, 2002, 383 pregnant females participated in the study, of which, 324 (84.6\%) had positive rubella IgG by ELISA and $59(15.4 \%)$ were negative or had equivocal results (Table 3 ). There were no significant differences seen in the rubella immune and susceptible groups as regards age, level of education, place of work, or history of rubella immunization. Only 3 women reported being immunized against rubella in the past, all of whom were seropositive. Among the 12 subjects who were unsure of their rubella immunization, 2 were found to be seronegative. No association was noted between rubella seropositivity and the factors studied (age, educational attainment, more than one pregnancy, age of gestation, and occupation).

\section{Discussion}

Our findings suggest that rubella, including congenital rubella syndrome, is an important public health problem in the Philippines, causing long-term disabilities such as deafness and other congenital disabilities. No prospective studies were conducted in the country on CRS detection, all the studies were retrospective, and most were hospital based; hence most of the cases with CRS that were reported were the ones that required acute care such as congenital heart diseases.

Based on the results of the seroprevalence studies, the number of susceptible women appeared to have declined in the Philippines since the 1980 s, wherein $37 \%$ of all women tested were susceptible to rubella [14]. In 2002, $15 \%$ of pregnant women in an urban setting remained susceptible to rubella. It is likely that the number of susceptible women has not changed substantially as RCV was introduced in the public health setting only in 2010 in young children. It is also likely that rubella susceptibility is higher in rural areas, as was observed in previous rubella susceptibility studies [10, 14].

In 2002, there were 1,666,773 live births in the Philippines [26]; if at least $15 \%$ of pregnant women were susceptible to rubella, then a substantial number of pregnancies would have been at risk for CRS. In the Philippines it is estimated that there are 100 to 149 CRS cases per 1,000 live births annually [27].

Similar to developing countries in the Western Pacific Region (WPR), the Philippines has recently introduced RCV. Routine surveillance data for CRS and rubella in the region are just being reported. In Myanmar, the burden of CRS during interepidemic periods was similar to that seen prior to the introduction of RCV in developed countries [28]. Following an outbreak of rubella in Vietnam, surveillance 
TABLE 1: Published studies of serologic surveys and clinical manifestations of congenital rubella syndrome (CRS) in the Philippines.

(a) Serologic surveys $(n=5)$.

\begin{tabular}{|c|c|c|c|c|c|c|}
\hline Author & Date & Setting & Methods & $\begin{array}{c}\text { Inclusion } \\
\text { criteria }\end{array}$ & Confirmatory test & Results \\
\hline $\begin{array}{l}\text { Espiritu- } \\
\text { Campos et al. } \\
1973[12]\end{array}$ & 1973 & $\begin{array}{l}\text { Community } \\
\text { setting (urban) }\end{array}$ & Prospective & $\begin{array}{c}\text { Male and female } \\
\text { volunteers } \\
(0-40 \text { years old })\end{array}$ & $\begin{array}{c}\text { Hemagglutination- } \\
\text { Inhibition } \\
\text { test }\end{array}$ & $\begin{array}{l}32.2 \% \text { rubella } \\
\text { susceptible }\end{array}$ \\
\hline $\begin{array}{l}\text { Del Mundo } 1973 \\
\text { [10] }\end{array}$ & 1973 & $\begin{array}{l}\text { Community } \\
\text { setting (urban } \\
\text { and rural) }\end{array}$ & Prospective & $\begin{array}{c}\text { Male and female } \\
\text { volunteers } \\
(0-40 \text { years old })\end{array}$ & $\begin{array}{c}\text { Hemagglutination- } \\
\text { Inhibition } \\
\text { test }\end{array}$ & $\begin{array}{l}26 \% \text { rubella } \\
\text { susceptible }\end{array}$ \\
\hline $\begin{array}{l}\text { Chan et al. } 1979 \\
{[13]}\end{array}$ & 1978 & $\begin{array}{l}\text { Community } \\
\text { setting (urban) }\end{array}$ & Prospective & $\begin{array}{c}\text { Nonpregnant } \\
\text { women (6-45 } \\
\text { years old) }\end{array}$ & $\begin{array}{c}\text { Hemagglutination- } \\
\text { Inhibition } \\
\text { test }\end{array}$ & $\begin{array}{c}29.6 \% \text { were rubella } \\
\text { susceptible }(38.1 \% \text { for } \\
\text { women } \leq 30 \text { years } \\
\text { old, } 12.5 \% \text { for }>30 \\
\text { years old })\end{array}$ \\
\hline $\begin{array}{l}\text { Alday et al. } 1982 \\
{[14]}\end{array}$ & 1982 & $\begin{array}{c}\text { Tertiary } \\
\text { hospitals (urban } \\
\text { Manila City and } \\
\text { rural Las Pinas) }\end{array}$ & Prospective & $\begin{array}{c}\text { Nonpregnant } \\
\text { women aged } \\
\text { (16-45 years } \\
\text { old })\end{array}$ & $\begin{array}{l}\text { Hemagglutination- } \\
\text { Inhibition } \\
\text { test }\end{array}$ & $\begin{array}{c}37.3 \% \text { were rubella } \\
\text { susceptible (urban } \\
\text { women } \leq 30 \text { years old, } \\
80 \% \text {; urban women }> \\
30 \text { years old, } 20 \% \text {; and } \\
\text { rural women } \leq 30 \\
\text { years old, } 64 \% \text {, rural } \\
\text { women }>30 \text { years } \\
\text { old, } 36 \% \text { ) }\end{array}$ \\
\hline $\begin{array}{l}\text { Yu et al. } 1997 \\
{[15]}\end{array}$ & 1997 & $\begin{array}{l}\text { Tertiary hospital } \\
\text { (Cebu City) }\end{array}$ & Prospective & $\begin{array}{c}\text { Pregnant } \\
\text { women (17-45 } \\
\text { years old) }\end{array}$ & $\begin{array}{l}\text { Microparticle Enzyme } \\
\text { Immunoassay (IgG) }\end{array}$ & $\begin{array}{l}10.9 \% \text { were rubella } \\
\text { susceptible }\end{array}$ \\
\hline
\end{tabular}

(b) Congenital rubella syndrome $(n=6)$.

\begin{tabular}{|c|c|c|c|c|c|c|}
\hline Author & $\begin{array}{l}\text { Month/year study } \\
\text { was conducted }\end{array}$ & $\begin{array}{c}\text { CRS } \\
\text { manifestation(s) } \\
\text { primarily used } \\
\text { to identify cases }\end{array}$ & Methods & $\begin{array}{l}\text { Included } \\
\text { subjects }\end{array}$ & $\begin{array}{c}\text { Diagnostic criteria for } \\
\text { CRS }\end{array}$ & Results \\
\hline $\begin{array}{l}\text { Nueva-Espana } \\
\text { et al. } 1988[16]\end{array}$ & $\begin{array}{l}\text { January } 1981 \text { to } \\
\text { June } 1986\end{array}$ & Hearing loss & $\begin{array}{l}\text { Retrospective } \\
\text { review of } \\
\text { audiology clinic } \\
\text { records and } \\
\text { audiologic test }\end{array}$ & $\begin{array}{l}\text { Children } 0-16 \\
\text { years old } \\
\text { presenting in a } \\
\text { tertiary hospital } \\
\text { with hearing } \\
\text { loss (mean } 4.7 \\
\text { years old) }\end{array}$ & $\begin{array}{c}\text { Hearing loss plus } \\
\text { maternal history of } \\
\text { febrile rash and other } \\
\text { signs associated with } \\
\text { CRS }\end{array}$ & $\begin{array}{l}17 \text { cases (out of } 496 \text { ) } \\
\text { had maternal history } \\
\text { of rubella, and only } 3 \\
\text { cases of the } 17 \text { were } \\
\text { diagnosed with CRS }\end{array}$ \\
\hline $\begin{array}{l}\text { Santos-Cabaero } \\
\text { et al. } 1998 \text { [17] }\end{array}$ & $\begin{array}{l}\text { January } 1990 \text { to } \\
\text { December } 1994\end{array}$ & $\begin{array}{c}\text { Cardiac, hearing } \\
\text { loss, and } \\
\text { cataract }\end{array}$ & $\begin{array}{l}\text { Retrospective } \\
\text { review of patient } \\
\text { records }\end{array}$ & $\begin{array}{c}\text { Children } \\
\text { diagnosed with } \\
\text { CRS by } \\
\text { physicians }\end{array}$ & $\begin{array}{c}\text { Rubella IgM } \\
\text { confirmed CRS cases }\end{array}$ & $\begin{array}{l}\text { Deafness and cataract } \\
\text { were the most } \\
\text { predominant } \\
\text { symptoms with } 26 \\
(62 \%) \text { and } 28(67 \%) \\
\text { cases, respectively. } \\
\text { Other clinical } \\
\text { findings included } \\
\text { were psychomotor } \\
\text { delay (50\%), } \\
\text { congenital heart } \\
\text { disease (45\%), } \\
\text { neonatal cholestasis } \\
(31 \%) \text {, and glaucoma } \\
\text { (4 cases or } 10 \%)\end{array}$ \\
\hline
\end{tabular}


TABle 1: Continued.

\begin{tabular}{|c|c|c|c|c|c|c|}
\hline Author & $\begin{array}{l}\text { Month/year study } \\
\text { was conducted }\end{array}$ & $\begin{array}{c}\text { CRS } \\
\text { manifestation(s) } \\
\text { primarily used } \\
\text { to identify cases }\end{array}$ & Methods & $\begin{array}{l}\text { Included } \\
\text { subjects }\end{array}$ & $\begin{array}{c}\text { Diagnostic criteria for } \\
\text { CRS }\end{array}$ & Results \\
\hline $\begin{array}{l}\text { Yu and Rameriz } \\
2003[18]\end{array}$ & $\begin{array}{l}\text { September to } \\
\text { October } 2002\end{array}$ & Hearing loss & $\begin{array}{l}\text { Prospective, } \\
\text { cross-sectional } \\
\text { study using } \\
\text { questionnaire }\end{array}$ & $\begin{array}{c}\text { Students } \\
\text { enrolled in a } \\
\text { School for the } \\
\text { Deaf (mean } 14.2 \\
\text { years old) }\end{array}$ & $\begin{array}{l}\text { Hearing loss plus } \\
\text { maternal history of } \\
\text { rubella }\end{array}$ & $\begin{array}{c}136(23.5 \%) \text { deaf } \\
\text { students had maternal } \\
\text { history of rubella, } \\
\text { among which } 15 \\
(2.6 \%) \text { had visual } \\
\text { problems and } 8(1.4 \%) \\
\text { had congenital heart } \\
\text { disease }\end{array}$ \\
\hline $\begin{array}{l}\text { Tecson and } \\
\text { Santiago } 2004 \\
{[19]}\end{array}$ & $\begin{array}{l}\text { January } 2000 \text { to } \\
\text { August } 2003\end{array}$ & Cataract & $\begin{array}{l}\text { Retrospective } \\
\text { review of patient } \\
\text { records }\end{array}$ & $\begin{array}{c}\text { Infants } \\
0-12 \text { mos with } \\
\text { atraumatic } \\
\text { cataract in a } \\
\text { tertiary hospital }\end{array}$ & $\begin{array}{l}\text { Congenital cataract } \\
\text { with history of } \\
\text { maternal measles and } \\
\text { heart disease }\end{array}$ & $\begin{array}{c}45 \text { cases (out of } 218 \\
\text { cases, or } 20.5 \% \text { ) had } \\
\text { CRS. } 18 \text { cases (out of } \\
218 \text { cases or } 8.2 \% \text { ) had } \\
\text { suspected CRS } \\
\text { CRS was the most } \\
\text { common cause of } \\
\text { secondary cataract }\end{array}$ \\
\hline Agnas 2005 [20] & $\begin{array}{l}\text { January } 1995 \text { to } \\
\text { December } 2002\end{array}$ & $\begin{array}{l}\text { Cardiac, } \\
\text { cataract, and } \\
\text { hearing loss }\end{array}$ & $\begin{array}{l}\text { Retrospective } \\
\text { review of patient } \\
\text { records }\end{array}$ & $\begin{array}{l}\text { Children } \\
\text { diagnosed with } \\
\text { CRS by } \\
\text { physicians }\end{array}$ & $\begin{array}{c}\text { Rubella IgM } \\
\text { confirmed CRS cases }\end{array}$ & $\begin{array}{c}\text { Cataract was the most } \\
\text { common clinical } \\
\text { manifestation, } \\
\text { followed by patent } \\
\text { ductus arteriosus at } \\
24(49 \%) \text { and } 15 \text { cases } \\
\text { (31\%), respectively. } \\
\text { The other clinical } \\
\text { manifestations were } \\
\text { hepatomegaly (10\%), } \\
\text { jaundice (10\%), } \\
\text { pulmonary artery } \\
\text { stenosis (6\%), } \\
\text { extrauterine growth } \\
\text { retardation (4\%), } \\
\text { glaucoma }(2 \%) \text {, and } \\
\text { hemolytic anemia } \\
(2 \%)\end{array}$ \\
\hline $\begin{array}{l}\text { Tipayno } 2008 \\
\text { [21] }\end{array}$ & $\begin{array}{l}\text { January } 1996 \text { to } \\
\text { December } 2005\end{array}$ & Hearing loss & $\begin{array}{l}\text { Retrospective } \\
\text { review of } \\
\text { audiologic } \\
\text { records }\end{array}$ & $\begin{array}{l}\text { Patients tested } \\
\text { in audiologic } \\
\text { clinic of a } \\
\text { pediatric } \\
\text { specialty tertiary } \\
\text { hospital (mean } \\
3.9 \text { years old) }\end{array}$ & $\begin{array}{l}\text { Clinically diagnosed } \\
\text { CRS (criteria used for } \\
\text { diagnosis not } \\
\text { mentioned) }\end{array}$ & $\begin{array}{c}48 \text { patients out of } \\
2,783(1.7 \%) \\
\text { physician-diagnosed } \\
\text { CRS } \\
44 \text { patients with CRS } \\
\text { (91\%) with hearing } \\
\text { loss, } 80 \% \text { of which } \\
\text { were severe to } \\
\text { profound hearing loss }\end{array}$ \\
\hline
\end{tabular}

for CRS in Vietnam yielded 292 cases of CRS [29]. In 2014 and 2015, 6 and 7 countries in the WPR have reported $>1$ confirmed rubella case per 1,000,000 population while no country reported a case of CRS [30]. In the Philippines, reporting CRS cases is not mandatory; hence the disease is likely underestimated. Surveillance on rubella has been integrated in measles-rubella surveillance, wherein patients presenting with rash and fever who tested negative for measles are eventually tested for rubella. This may also be an underestimate as most cases of rubella have an indolent course. Nevertheless, the country reported 3.4 and 1.5 and 1.4 (annualised) laboratory-confirmed rubella cases per $1,000,000$ population in 2014,2015 , and 2016 , respectively [30].

The WHO recommends two approaches for rubella immunization. The first recommends immunization of adolescent and adult women of childbearing age, aimed at reducing the burden of CRS. The second, which is suitable for elimination of both rubella and CRS, interrupts the transmission of rubella virus by the introduction of RCV into the routine childhood immunization schedule in combination with the vaccination of older age groups [3]. 
TABLE 2: Unpublished studies $(n=4)$ on congenital rubella syndrome.

\begin{tabular}{|c|c|c|c|c|c|}
\hline Author & Year & Sign & Methods & Included subjects & Results \\
\hline $\begin{array}{l}\text { Tanglao-Salazar } \\
1993 \text { [22] }\end{array}$ & 1993 & Hearing loss & $\begin{array}{l}\text { Retrospective chart } \\
\text { review }\end{array}$ & $\begin{array}{l}\text { Children with hearing } \\
\text { impairment }\end{array}$ & $\begin{array}{c}18.4 \% \text { with maternal } \\
\text { history of rubella infection } \\
\text { during pregnancy }\end{array}$ \\
\hline $\begin{array}{l}\text { Rodriguez } 1995 \\
{[23]} \\
\end{array}$ & 1995 & Hearing loss & $\begin{array}{c}\text { Retrospective chart } \\
\text { review }\end{array}$ & $\begin{array}{c}\text { Children with hearing } \\
\text { impairment }\end{array}$ & $\begin{array}{l}13 \% \text { diagnosed with } \\
\text { congenital rubella }\end{array}$ \\
\hline $\begin{array}{l}\text { Santos-Gonzales } \\
\text { and Santiago } \\
2013[24]\end{array}$ & 2013 & Cataract & $\begin{array}{l}\text { Retrospective review } \\
\text { of records in pediatric } \\
\text { ophthalmology clinic }\end{array}$ & $\begin{array}{l}\text { Children with suspected, } \\
\text { probable, or } \\
\text { laboratory-confirmed CRS }\end{array}$ & $\begin{array}{c}\text { Out of } 23 \text { cases, there were } \\
6(26 \%) \text { rubella IgM } \\
\text { confirmed, } 11(48 \%) \\
\text { probable, and } 6(26 \%) \text { CRS } \\
\text { suspected cases. Cataract } \\
\text { was seen in } 21(91 \%) \text { of the } \\
\text { cases of CRS. Two patients } \\
\text { presented with pigmentary } \\
\text { retinopathy }\end{array}$ \\
\hline $\begin{array}{l}\text { Limgenco } 2000 \\
{[25]}\end{array}$ & 2000 & Pregnancy outcome & Retrospective review & $\begin{array}{l}\text { Pregnant women with } \\
\text { TORCH }^{\mathrm{b}} \text { titers }\end{array}$ & $\begin{array}{c}4 \text { cases of maternal rubella } \\
\text { infection, } 1 \text { had fetal death } \\
\text { in utero, and } 3 \text { babies were } \\
\text { diagnosed with congenital } \\
\text { rubella syndrome }\end{array}$ \\
\hline
\end{tabular}

${ }^{a}$ The 1997 US CDC criteria for CRS include the following. Clinical description: an illness is usually manifesting in infancy resulting from rubella infection in utero and characterized by signs or symptoms from the following categories: (A) cataracts/congenital glaucoma, congenital heart disease (most commonly patent ductus arteriosus, or peripheral pulmonary artery stenosis), loss of hearing, and pigmentary retinopathy; (B) purpura, splenomegaly, jaundice, microcephaly, mental retardation, meningoencephalitis, and radiolucent bone disease. Case classification: suspected: a case with some compatible clinical findings but not meeting the criteria for a probable case; probable: a case that is not laboratory confirmed and that has any two complications listed in paragraph (A) of the clinical description or one complication from paragraph (A) and one from paragraph (B) and lacks evidence of any other etiology; confirmed: a clinically compatible case that is laboratory confirmed; infection only: a case that demonstrates laboratory evidence of infection, but without any clinical symptoms or signs. Laboratory confirmation is through viral isolation, rubella IgM, and rubella antibody level that persists at a higher level and for a longer period than expected from passive transfer of maternal antibody.

b TORCH: toxoplasma, rubella, cytomegalovirus, herpes titers.

TABLE 3: Characteristics of pregnant women and their rubella serologic status, 2002.

\begin{tabular}{|c|c|c|c|c|}
\hline Variable & $N$ & Immune $n\left(\%, 95 \% \mathrm{CI}^{\mathrm{a}}\right)$ & Susceptible $n\left(\%, 95 \% \mathrm{CI}^{\mathrm{a}}\right)$ & $P$ value \\
\hline Age & & & & 0.33 \\
\hline $16-25$ & 176 & $152(86.36,80.39-91.06)$ & $24(13.64,8.94-19.61)$ & \\
\hline $26-35$ & 168 & $142(84.52,78.15-89.63)$ & $26(15.48,10.37-21.85)$ & \\
\hline $36-45$ & 39 & $30(76.92,60.67-88.87)$ & $9(23.08,11.13-39.33)$ & \\
\hline Education & & & & 0.88 \\
\hline Elementary & 21 & $17(80.95,58.9-94.55)$ & $4(19.05,5.45-41.91)$ & \\
\hline High school & 180 & $152(84.44,78.31-89.41)$ & $28(15.56,10.59-21.69)$ & \\
\hline College & 182 & $155(85.16,79.15-89.99)$ & $27(14.84,10.01-20.85)$ & \\
\hline Work & & & & 0.21 \\
\hline Primarily at home & 294 & $245(83.33,78.57-87.41)$ & $49(16.67,12.59-21.43)$ & \\
\hline Primarily outside & 89 & $79(88.76,80.30-94.47)$ & $10(11.24,5.52-19.69)$ & \\
\hline History of rubella immunization & & & & 0.75 \\
\hline None & 368 & $311(84.51,80.40-88.05)$ & $57(15.49,11.95-19.6)$ & \\
\hline Yes & 3 & $3(100)$ & 0 & \\
\hline Unknown & 12 & $10(83.33,51.58-97.91)$ & $2(16.67,2.09-48.41)$ & \\
\hline
\end{tabular}

${ }^{\mathrm{a}}$ Exact binomial 95\% confidence interval.

In view of the regional goal of rubella elimination, RCVs have been introduced in the Philippines at 9 and 12-15 months of age as well as at 7 years of age in schools. However, rubella susceptibility screening is not routinely conducted among pregnant women and immunization of women of child bearing age has not been included in the public health setting. Continued vigilance and enhanced surveillance for CRS and rubella are important in identifying cases to attain the regional goal of rubella elimination. 


\section{Conclusions}

Our review presents the baseline information on rubella and CRS and supports the establishment of CRS surveillance in the country to identify the burden, as well as for programmatic implementation to monitor the impact of immunization.

\section{Competing Interests}

The authors declare that they have no competing interests.

\section{References}

[1] F. T. Cutts, S. E. Robertson, J.-L. Diaz-Ortega, and R. Samuel, "Control of rubella and congenital rubella syndrome (CRS) in developing countries, part 1: burden of disease from CRS," Bulletin of the World Health Organization, vol. 75, no. 1, pp. 5568, 1997.

[2] S. E. Robertson, F. T. Cutts, R. Samuel, and J.-L. Diaz-Ortega, "Control of rubella and congenital rubella syndrome in developing countries, part 2: vaccination against rubella," Bulletin of the World Health Organization, vol. 75, no. 1, pp. 69-80, 1997.

[3] World Health Organization, "Rubella vaccine: WHO position paper," The Weekly Epidemiological Record, vol. 86, pp. 301-316, 2011.

[4] G. B. Grant, S. Reef, A. Dabbagh, M. Gacic-Dobo, and P. Strebel, "Global progress toward rubella and congenital rubella syndrome control and elimination-2000-2014," The Weekly Epidemiological Record, vol. 90, no. 39, pp. 510-516, 2015.

[5] World Health Organization, WHO-vaccine preventable diseases monitoring system 2015 global summary Geneva, 2016, http://apps.who.int/immunization_monitoring/globalsummary/ timeseries/tsincidencecrs.html.

[6] O. Adam, A. K. M. Ali, J. M. Hübschen, and C. P. Muller, "Identification of congenital rubella syndrome in Sudan," BMC Infectious Diseases, vol. 14, no. 1, article 305, 2014.

[7] World Health Organization, "Regional Committee for the Western Pacific: elimination of measles and rubella control," Tech. Rep. WPR/RC63.R5, Regional Office of the Western Pacific, Manila, Pa, USA, 2012.

[8] WHO, Expanded Programme on Immunization: Regional framework for Implementation of the Global Vaccine Action Plan in the Western Pacific Manila: Regional Office of the Western Pacific, WHO, Geneva, Switzerland, 2014, http://www.wpro .who.int/about/regional_committee/65/documents/wpr_rc065_ 08_epi_en.pdf.

[9] R. B. Soriano, G. S. Fernando, R. Ng, and B. Q. Pecache, "Clinical and serologic evaluation of the combined measles-mumpsrubella vaccine," Philippine Journal of Pediatrics, vol. 38, no. 3, pp. 133-138, 1987.

[10] F. Del Mundo, "The serodiagnosis of rubella in the Philippines based on hemagglutination-inhibition determination in rural and urban populations," Philippine Journal of Pediatrics, vol. 22, pp. 105-112, 1973.

[11] World Health Organization, Measles-Rubella Bulletin, Regional Office for the Western Pacific Region, Manila, Philippines, 2010, http://iris.wpro.who.int/bitstream/handle/10665.1/11129/ Measles-Rubella_Bulletin_2010_Vol_04_No_03.pdf?sequence=1.
[12] L. Espiritu-Campos, F. Caoili, and E. F. Almagro, "Rubella and measles antibodies in some Filipinos," Acta Medica Philippina, vol. 9, no. 1, pp. 13-17, 1973.

[13] V. F. Chan, S. P. Salenda, and M. R. Maaba, "Susceptibility of rubella infection among Filipino women," Philippine Journal of Microbiology and Infectious Diseases, vol. 8, no. 1, pp. 26-32, 1979.

[14] A. R. Alday, A. R. Singson-Alday, M. A. Chan et al., "Incidence of rubella among Filipino women of child-bearing age group," Philippine Journal of Obstetrics and Gynecology, vol. 6, no. 2, pp. 90-94, 1982.

[15] C. T. Yu, M. A. Chan, and I. A. Layno, "Rubella susceptibility in pregnant women at Cebu Doctors' Hospital," CDU Proceedings, vol. 13, no. 1, pp. 91-94, 1997.

[16] E. Nueva-Espana, H. Nueva-Espana, J. Acuin, and R. Caro, "Retrospective analysis of results of audiometric tests in Filipino children," Philippine Journal of Otolaryngology Head and Neck Surgery, pp. 607-610, 1988.

[17] A. M. E. Santos-Cabaero, O. Q. Malanyaon, E. T. Ty, and E. E. Ortiz, "Profile of congenital heart disease in Filipino children with congenital rubella syndrome," Philippine Journal of Pediatrics, vol. 47, no. 1, pp. 52-54, 1998.

[18] O. Yu and G. Rameriz, "Socio-demographic and clinical profile of students enrolled in ten schools for the deaf in Metro Manila," Philippine Children's Medical Center Journal, vol. 4, no. 2, pp. 3752, 2003.

[19] J. V. Tecson and A. P. D. Santiago, "Profile of childhood cataract cases at the Philippine General Hospital," Philippine Journal of Ophthalmology, vol. 29, no. 3, pp. 140-143, 2004.

[20] C. L. Agnas, "The analysis of clinical and social profile of congenital rubella syndrome seen among UP-PGH patients from years 1993-2002: a 10 year prevalence review," Pediatric Infectious Disease Society of the Philippines Journal, vol. 9, no. 2, pp. 51-56, 2005.

[21] M. J. C. Tipayno, "A 10-year review of brainstem auditory evoked response testing at the Philippine Children's Medical Center: patient demographics and outcomes," Philippine Journal of Otolaryngology Head and Neck Surgery, vol. 23, no. 2, pp. 17-22, 2008.

[22] N. Tanglao-Salazar, "Demographic and clinical profile of hearing impaired pediatric patients," in Proceedings of the Philippine General Hospital Residents Research, Philippine General Hospital, Manila, Philippines, 1993.

[23] L. Rodriguez, "Clinical profile of deafness in children seen at the Child Development Clinic," in Presented at Philippine General Hospital Resident's Research, Philippine General Hospital, Manila, Pa, USA, 1995.

[24] M. A. M. Santos-Gonzales and A. P. D. Santiago, Ocular Findings of Congenital Rubella Patients in a Tertiary Hospital Setting, Presented at Philippine General Hospital Fellow's Research, Philippine General Hospital, Manila, Philippines, 2002.

[25] A. Limgenco, TORCH Infections among High Risk Pregnancies, Presented at the Philippine General Hospital Resident's Research, Philippine General Hospital, Manila, Philippines, 2000.

[26] Department of Health National Epidemiology Center, Philippine Health Statistics 2002, Department of Health, Manila, Pa, USA, 2002.

[27] E. Vynnycky, E. J. Adams, F. T. Cutts et al., "Using seroprevalence and immunisation coverage data to estimate the global burden of congenital rubella syndrome, 1996-2010: a systematic review," PLoS ONE, vol. 11, no. 3, Article ID e0149160, 2016. 
[28] K.-Z. Thant, W.-M. Oo, T.-T. Myint et al., "Active surveillance for congenital rubella syndrome in Yangon, Myanmar," Bulletin of the World Health Organization, vol. 84, no. 1, pp. 12-20, 2006.

[29] K. Toda, S. Reef, M. Tsuruoka et al., "Congenital rubella syndrome (CRS) in Vietnam 2011-2012-CRS epidemic after rubella epidemic in 2010-2011," Vaccine, vol. 33, no. 31, pp. 36733677, 2015.

[30] World Health Organization, Measles-Rubella Bulletin Manila: Regional Office for Western Pacific Region, 2016, http://iris .wpro.who.int/bitstream/handle/10665.1/13387/Measles-Rubella_ Bulletin_2016_Vol_10_No_06.pdf. 


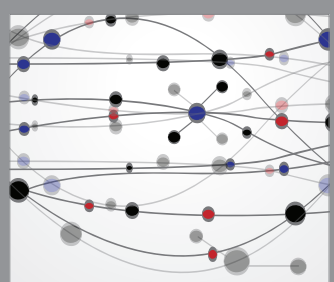

The Scientific World Journal
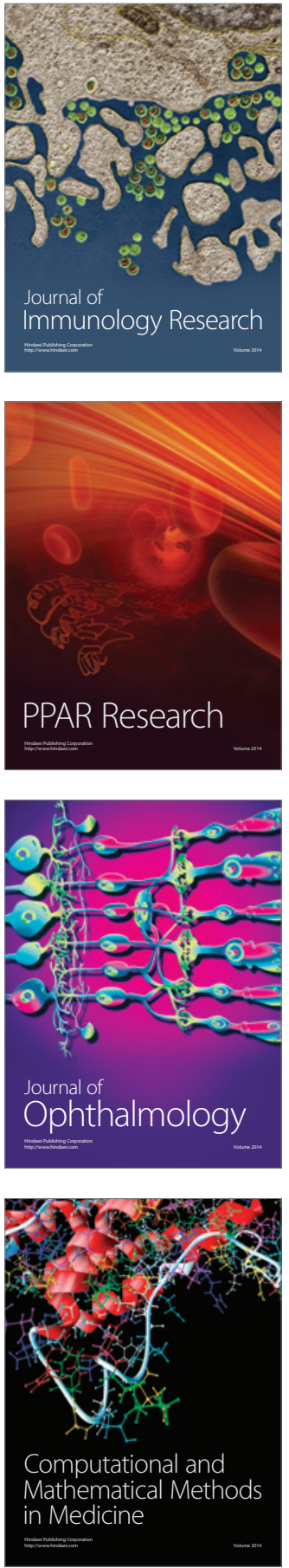

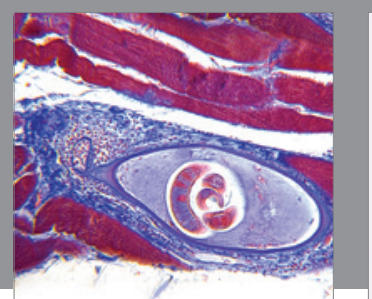

Gastroenterology Research and Practice

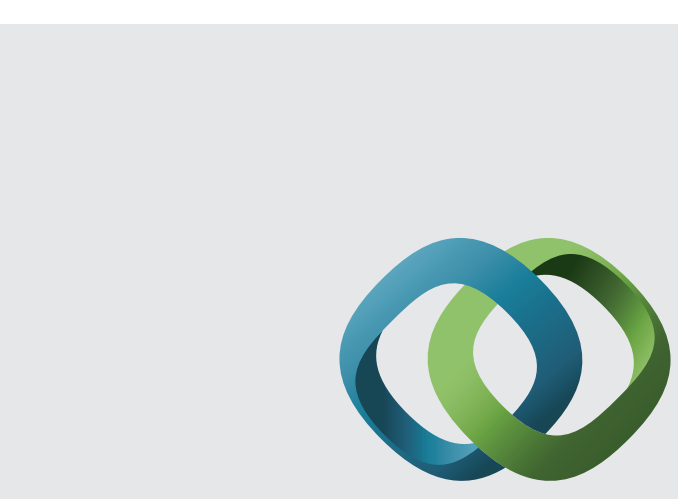

\section{Hindawi}

Submit your manuscripts at

http://www.hindawi.com
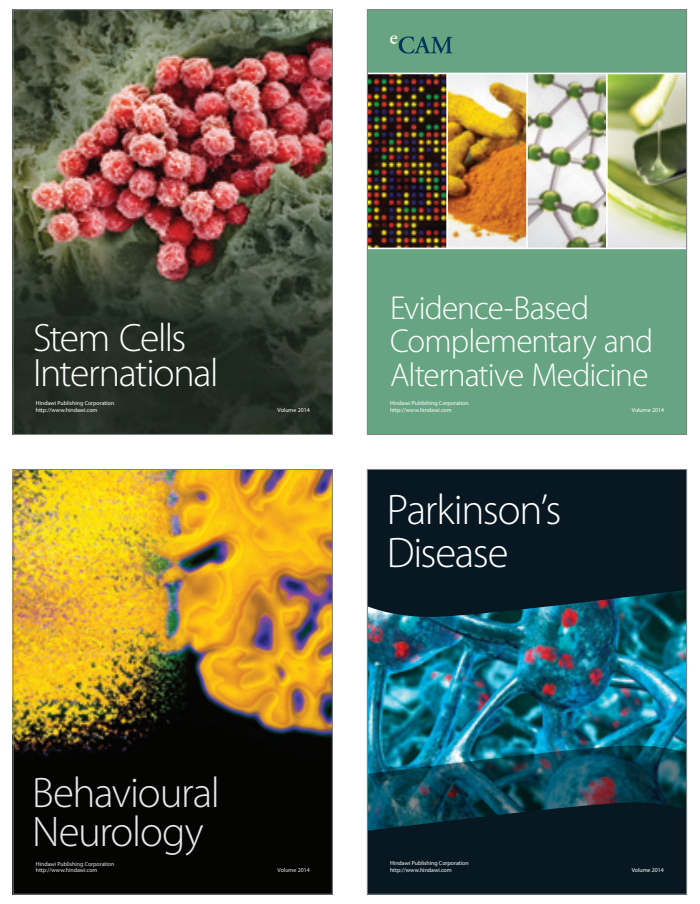
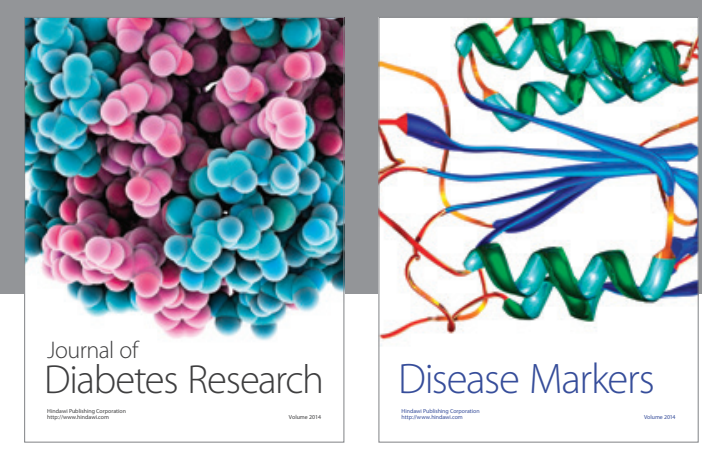

Disease Markers
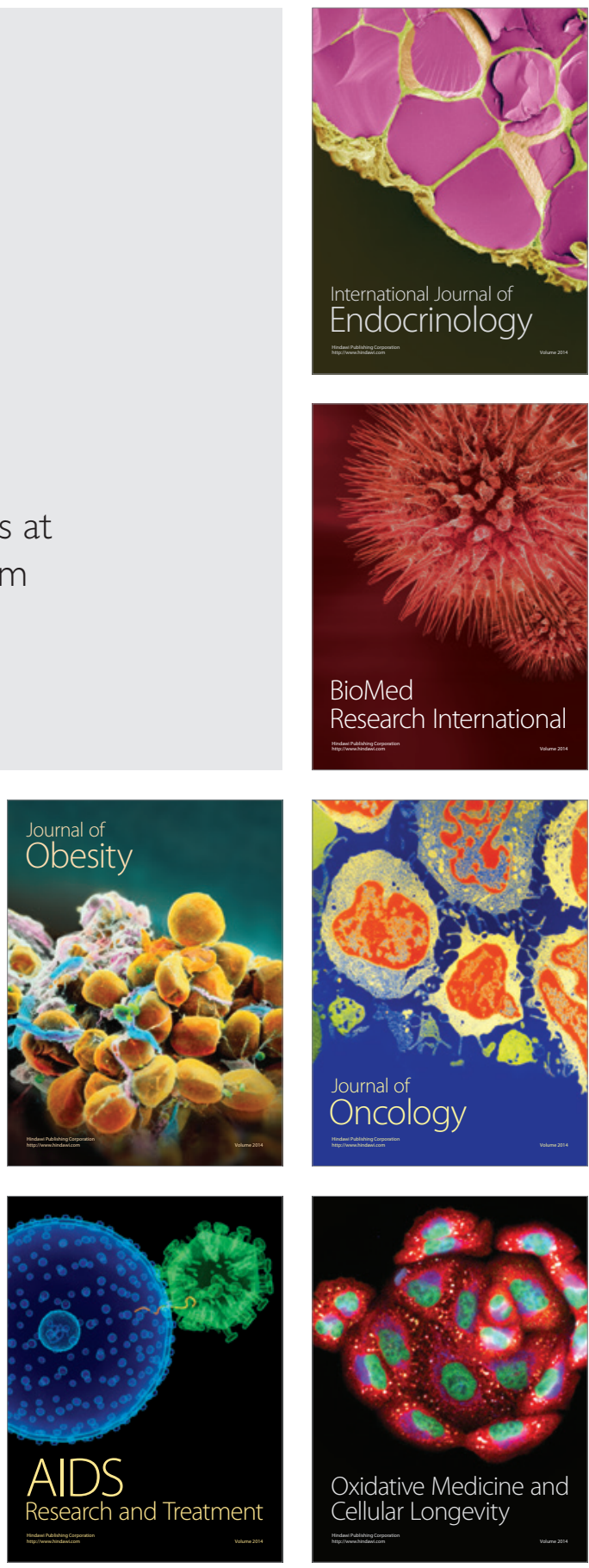